\title{
Build Environmental Awareness through Learning Indonesian
}

Wira Santika / 18016195

Wirasantika03022000@gmail.com

Not only in Indonesia, but all over the world experiencing environmental damage. According to Mitsuki and Lai (in Ramadhan et al, 2019) around the world, everyone faces serious environmental problems, such as global warming, rain, acid, ozone layer destruction, environmental pollution, natural damage, and loss of life-threatening biodiversity. current generation, especially future generations. Environmental problems are caused by careless human activities towards nature in order to fulfill and improve their quality of life (Huang and Kawata, in Ramadhan et al, 2019). A more threatening aspect is the unconsciousness of human influence on their environment. The community is currently faced with environmental problems that cause natural disasters.

One of the environmental problems facing Indonesia is the problem of waste. Seeing the environmental conditions during the current Covid-19 Pandemic, in Indonesia the increasing amount of household waste and medical waste, as well as environmental pollution from spraying disinfectare. Medical waste that has increased drastically in the form of medical plastics, gloves, disposable masks, syringes, radioactive waste, and infectious waste that can transmit dangerous diseases. Many Indonesian people are not aware of the importance of disposing of waste properly. At the time of Covid-19, there were lots of rubbish such as latex gloves and masks that filled the beaches, rivers and gutters, even divers also found a lot of medical waste such as masks and personal protective equipment on the seabed.

Lai (in Ramadhan et al, 2019) said that environmental problems are inherently inseparable from environmental awareness, values, and human attitudes. This prompted countries to start assessing environmental education. Environmental education is a process to build human populations in the world who are aware and care about the total environment (as a whole) and all the problems related to it, and people who have the knowledge, skills, attitudes and behavior, motivation and commitment to work together, 
both individually and collectively, to be able to solve various environmental problems today, and prevent the emergence of new problems (UNESCO, Tbilisi Declaration, 1977).

It is important that environmental education is given to students as early as possible so that students are accustomed to always protecting the surrounding environment. Environmental education that is first obtained by students is in the nuclear family environment, this is because before students study at school, students learn from their parents about the importance of protecting the environment. Apart from the nuclear family, the surrounding community can also provide lessons about caring for the community environment. It is only at school age that school teachers continue learning about the environment more fully. However, to incorporate environmental education into language learning is not easy. Teachers must have the necessary knowledge and environmental readiness for activities in the classroom to be effective (Ramadhan et al, 2019).

If it is connected with Indonesian, the topic of environment can be included in Indonesian language learning in the form of text, this is because these topics can also be integrated into other subjects (Ramadhan et al, 2019). According to Rivers (in Ramadhan et al, 2019) said as language teachers, we are the luckiest teachers, all subjects are ours. Whatever our students want to communicate, whatever they want to read is our subject matter. According to Hauchild, Poltavthenko and Stoller (in Ramadan et al, 2019) language teachers are in a unique position to promote environmental awareness.

The data in this essay comes from distributing a questionnaire via watsapp which contains ten statements with the options to strongly agree, agree, disagree, and disagree with the topic of the Importance of Environmental Materials to 40 respondents. The research results are as follows:

First, the environment can be used as a source of Indonesian language learning which aims as a process of communication or interaction between communities. 50\% strongly agree and $50 \%$ agree.

Second, with the environment as a learning medium, students are more familiar with the environment so that it fosters a sense of love for the environment. 50\% strongly agree and $50 \%$ agree. 
Third, all the environment around can be used as a medium for learning Indonesian. 17.5\% strongly agree, $72.5 \%$ agree, and $10 \%$ disagree.

Fourth, providing environmental material in Indonesian language learning is an effort to build ecological intelligence. $42.5 \%$ strongly agree, $52.5 \%$ agree, and 5\% disagree.

Fifth, the use of Indonesian in the school environment is more effective than regional languages. $35 \%$ strongly agree, $57.5 \%$ agree, and $7.5 \%$ disagree.

Sixth, environmental material in Indonesian language learning in schools is an alternative to foster student interest and enthusiasm. 32.5\% strongly agree, 62.5\% agree, and 5\% disagree.

Seventh, environmental preservation efforts through reading texts in Indonesian language learning provide an overview of students' high knowledge of nature. 30\% strongly agree and $70 \%$ agree.

Eighth, environmental material makes it easier for students to understand Indonesian language learning well. $32.5 \%$ strongly agree, $55 \%$ agree, and $12.5 \%$ disagree.

Ninth, environmental material is very important to be applied in learning Indonesian. 45\% strongly agree, $50 \%$ agree, and 5\% disagree.

Tenth, the environment can be the most preferred learning media. $32.5 \%$ strongly agree, $62.5 \%$ agree, and $5 \%$ disagree.

From the results of the research through the questionnaire that the author has done, it can be concluded that many students, students, and teachers agree and even strongly agree to link environmental material with Indonesian language learning. By learning Indonesian, the teacher can introduce and build students 'awareness of the environment, so as to increase students' sense of care for the environment. 


\section{Referensi}

Akman O and Alagoz B. 2017. A study on environmental-oriented knowledge, attitude and behavior level of teacher candidates Journal of Education and Practice 8(1) 229-45

Bergman, B. G. (2016). Assessing impacts of locally designed environmental education projects on students' environmental attitudes, awareness, and intention to act Environmental Education Research 22(4) 480-503.

Buldur, A . and Omeroglu, E. (2018). An examination of the relationship between preschool children's and their teacher' attitute and awareness towards the environment Journal of Education ang Learning 7(2) 221-9.

Erdogan M. 2015. The effect of summer environmental education program (SEEP) on elementary school students' environmental literacy International J. Sci. Env. Ed. 10(2) 165-181.

Hauchild S, Poltavthenko E and Stoller F L. (2012). Going green: Menging environmental education and language instruction English Teaching Forum 2-13.

Kollmuss A and Agyeman J. (2002). Mind the gap: Why do people act enviconmentally and what are the barriers to pro-environmental behavior Environmental Education Research 239-60.

Lai, C.S., Sukma, E., \& Indriyani, V. (2019). Enviromental learning outcomes in taipei International Journal of Research in Education and Science 4(1) 252-61.

Mitsuki I. (2017) Beyond the limitations of environmental education in Japan Educational Studies in Japan: International Yearbook 3-14.

Napoli M. (2011) Going green: Empowering readers to change the environment Kappa Delta Pi Record 4776-9.

Nazarenko, A.V. and Kolesnik, A.I. (2018). Raising environmental awareness of future teachers International Journal of Instruction 11(3) 63-76.

Nkwetisma C M. (2011) EFL/ESL and environmental education: towards an eco applied linguistic awareness in Cameroon World Journal of Education 1 110-18.

Ramadhan, S., Sukma, E., \& Indriyani, V. (2019). Environmental education and disaster mitigation through language learning. IOP Conference Series: Earth and Environmental Science, 314. 
